\title{
ИЗ НАБЛЮДЕНИЙ НАД МИФОЛОГИЧЕСКИМИ ОБРАЗАМИ В ЦИКЛЕ ПУТЕВЫХ ОЧЕРКОВ ИВАНА БУНИНА ТЕНЬ ПТИЦЫ - МЕЖДУ ЛЕГЕНДОЙ И ПРЕДАНИЕМ
}

\author{
MAJA WIĘCKOWSKA \\ Uniwersytet Warszawski \\ Wydział Lingwistyki Stosowanej \\ ul. Dobra 55, 00-312 Warszawa, Polska \\ e-mail: maja.wieckowska@wp.pl \\ (nadesłano: 30.08.2017; zaakceptowano 5.09.2017)
}

\section{Abstract \\ From observations on the mythological images in travel essays Bird's Shadow by Ivan Bunin - between a legend and a tale}

The article is an attempt to analyze the selected legends reflected in Ivan Bunin's travel essays Bird's Shadow. The cycle of essays contains elements taken from the mythology of many different cultures. These include stories about the founding of cities, legends related to symbolic images, stories about famous historical and religious figures and fantastic creatures. Mythological images provided by Ivan Bunin are multifunctional, and each of them sends the reader to other images and at the same time enriches the image of cultural and historical memory.

\section{Key words:}

Ivan Bunin, Bird's Shadow, myth, mythology, legend, tale. 


\section{Abstrakt \\ Z obserwacji nad mitologicznymi obrazami w szkicach podróżniczych Iwana Bunina Cień ptaka - między legendą a podaniem}

Artykuł jest próbą analizy wybranych legend odzwierciedlonych w szkicach podróżniczych Iwana Bunina Cień ptaka. Cykl zawiera elementy zaczerpnięte z mitologii wielu różnych kultur. Są to między innymi opowieści o założeniu miast, legendy związane z wizerunkami-symbolami, opowiadania o znanych historycznych i religijnych postaciach, a także o fantastycznych stworzeniach. Mitologiczne obrazy przytoczone w tekście przez Iwana Bunina są wielofunkcyjne, a każdy z nich odsyła czytelnika do innych obrazów i jednocześnie wzbogaca wyobrażenie o kulturowej i historycznej pamięci.

\section{Słowa kluczowe}

Iwan Bunin, Cień ptaka, mit, mitologia, legenda, podanie.

Очерки цикла Тень птицы создавались в 1907-1911 годах одновременно с Деревней и Суходолом. Этот период был началом расцвета бунинского дарования, которому в немалой степени способствовали постоянные путешествия писателя по миру. „Он не только изъездил Россию и Европу, но странствовал по Африке, съездил в Палестину, на Цейлон. В Константинополе побывал тринадцать раз!"1. Путешествия играли в жизни Бунина важную роль. Многие исследователи (например, К. Цеслик, Ю. Мальцев, И. П. Вантенков) подчёркивают, однако, что никакие другие путешествия не принесли таких плодотворных результатов как путешествия на Восток. „Восток” для Бунина - „это чарующие страны древней культуры и мифа, прародина человечества, доисторический Рай"2.

Своё первое путешествие на Восток Бунин совершил в 1903 году. Перед этой поездкой „он в первый раз целиком прочел Коран, который очаровал его, и ему хотелось непременно побывать в городе, завоеванном магометанами, полном исторических воспоминаний, сыгравшем такую роль в православной России, особенно в Московском царстве"'. Константинополь, в котором Иван Бунин пребывал в течение месяца, поразил его своей красотой. Это событие было одним из самых важных, благотворных и поэтических в жизни писателя 4 .

Во второе странствие в древние страны Востока писатель отправился со своей будущей женой Верой Муромцевой в 1907 году. 4 мая 1907 года Иван Алексеевич писал Н. Д. Телешову:

1 Л.В. Крутикова. Комментарии. [В:] Бунин И.А. Собрание сочинений в 9-ти томах. Т. 3. Москва: Художественная литература, 1965-66, с. 655.

2 Ю. Мальцев. Иван Бунин 1870-1953. Москва: Посев, 1994, с. 23.

3 А.К. Бабореко. Бунин: жизнеописание. Москва: Молодая гвардия, 2009, с. 85.

4 Там же, с. 87. 
„Дорогой друг, совершаем отличное путешествие. Были в Царьграде, в Афинах, Александрии, Яффе, Иерусалиме, Иерихоне, Хевроне, у Мертвого моря! Теперь пишу тебе из Сирии, - из Бейрута. Завтра - в Дамаск, потом в Назарет, Тивериаду, Порт-Саид, Каир и, посмотревши пирамиды, - домой, снова через Афины" 5 .

Писатель не расставался тогда со стихами любимого персидского поэта Саади, словами которого он часто определял смысл своих собственных странствий ${ }^{6}$. Хотя очерки цикла Тень птищы были созданы непосредственно в результате второго путешествия, но они, всё-таки, являются плодом двух поездок писателя (1903 и 1907 годов).

В Тени птицы присутствует не только современность, но и история, в том числе архаическая культура народов Востока. В связи с этим необходимо обратить внимание на очень значимую роль мифов. Поскольку существует немного собственно исторических текстов архаического периода, то „мифологические источники при всей своей неполноте и неточности восполняют (хотя и в специфической форме) исторические источники, помогают в решении задач истории как познания"7. Запечатленные в мифах упоминания, названия конкретных лиц, имена собственные, культурологические знаки несут информацию об ушедших цивилизациях. Прошедшее, в свою очередь, даже если подверглось разрушениям, не исчезает. Оно сохраняется не только в древних руинах, но и в преданиях и легендах.

Некоторые исследователи (например, Г. Г. Исаев, И. А. Таирова и др.) обращают внимание на наличие в Тени птицы многих интертекстуальных элементов. В произведении обнаруживаются цитаты и реминисценции из Библии, Нового и Ветхого Заветов, Корана, Талмуда, Книги мёртвых, Книги пирамид, Каббалы, древних авторов и мифологий. Интертекстуальные вкрапления вводятся в текст повествователем для того, чтобы передать колорит прошлого, документально закрепить его истинность и достоверность ${ }^{8}$.

В обиходном понимании миø - это античные, библейские и другие старинные тексты, которые повествуют о сотворении мира и человека, а также о деяниях богов и героев. Слово миф по преимуществу ассоциируется с древними греческими и римскими текстами, как правило, поэтическими, наивными, нередко причудливыми. Такое представление о мифах является результатом включения античной культуры в круг знаний европейского человека - само слово миø происходит из греческого языка 9 . Согласно общепринятому определению, „Мифы (от греч. mythos - повествование, басня, предание), создания коллективной

\footnotetext{
5 Там же, с. 104.

6 Л.В. Крутикова. Комментарии. [В:] Бунин И. А. Собрание сочинений в 9-ти томах. Т. 3. Москва: Художественная литература, 1965-1966, с. 594.

7 В.Н. Топоров. История и мифы. [В:] Мифы народов мира: энизилопедия. Т. 1. Гл. ред. С.А. Токарев. Москва: Советская энциклопедия, 1987, с. 572.

8 И.П. Вантенков. Лирические минятюры и путевые поэмы. [В:] Бунин-повествователь (рассказы 1890-1916 г2.). Минск: Издательство Белорусского университета, 1974, с. 66.

9 С.А. Токарев, Е.М. Мелетинский. Мифология. [В:] Мифы народов мира: энциклопедия. Т. 1, c. 11 .
} 
общенародной фантазии, обобщенно отражающие действительность в виде чувственно-конкретных персонификаций и одушевлённых существ, которые мыслятся первобытным сознанием вполне реальными"10. Однако в Тени птиць читатель имеет дело не только с античными мифами, но и, прежде всего, со сказаниями восточных народов (ветхозаветными, христианскими, кораническими, иудейскими, аравийскими, ханаанскими, египетскими и др.). Надо обратить внимание, что применительно к этим сказаниям сам Иван Бунин употребляет в произведении понятие „легенда”. Слово миф не используется автором.

Автор словарной статьи К. В. Чистов указывает: „Легенда (от лат. legenda, буквально - то, что следует прочесть)" ${ }^{11}$. Он различает два типа легенд. К первому типу относятся „литературные легенды”. Первоначально это были жития святых и патериковые рассказы, а со временем легендами стали называть разнообразные повествования религиозного характера. Легендам присущи такие свойства, как благочестивость и поучительность. Второй тип - это „фольклорные легенды”, т.е. вошедшие в традицию устные народные рассказы. Как правило, в их основе лежит чудо, фантастический образ или представление, которое воспринимается как достоверное. В современном обиходном значении легендой часто называют произведения любого жанра, отличающиеся поэтическим и „сверхъестественным” вымыслом и одновременно претендующие на некую достоверность в прошлом ${ }^{12}$.

Г. А. Левинтон, причисляющий легенду к группе фольклорных произведений, замечает, что эти тексты в разных культурных традициях описывают не вполне сходные явления и по-разному соотносятся с другими фольклорными жанрами. По его мнению, общей чертой для легенд разных традиций является их приуроченность к историческому времени, или, по крайней мере, к переходу от мифологического времени к историческому. Повествования о „заранее” известных лицах, событиях и времени, в историчности которых не сомневается носитель, Г. А. Левинтон разделяет на легенды и предания ${ }^{13}$. По его мнению „легенды связаны преимущественно с персонажами священной истории (напр., христианскими или исламскими святыми, евангельскими персонажами), предания же - с персонажами мирской истории, причем элемент чудесного в них не обязателен" 14 .

В Тени птицы обнаруживаются оба типа повествований - легенды и предания. Что касается понятий „миф” и „легенда” (которые в разных традициях могут противопоставляться друг другу), то они все же, как правило, объединяются по признаку уверенности носителей в достоверности сообщаемого и нали-

10 С.С. Аверинцев, М.Н. Эпштейн. Мифы. [В:] Литературный энциклопедический словарь. Под ред. В.М. Кожевникова и П.А. Николаева. Москва: Советская энциклопедия, 1987, с. 222.

11 К.В. Чистов. Легенда. [В:] Литературный энциклопедический словарь..., с. 177.

12 Там же.

13 Там же.

14 Г.А. Левинтон. Легенды и мифыь. [В:] Мифы народов мира: энциклопедия. Т. 2. Гл. ред. С.А. Токарев. Москва: Советская энциклопедия, 1987, с. 45. 
чии элемента чудесного ${ }^{15}$. По отношению к путевым очеркам И. Бунина ближе определение „легенда”. Вслед за автором произведения мы оперируем этим понятием.

Как замечает И. А. Таирова, мифология, наряду с религией, часто составляла основу мировоззрения древних народов Востока. Для того, чтобы глубже проникнуть в содержание путевых очерков, отразивших историю, культуру, традиции и быт восточных народов, необходимо рассмотреть некоторые из легенд, вошедших в цикл Тень птицы.

Н. А. Николина в своём учебном пособии Поэтика русской автобиограбической прозы обращает внимание на то, что роль мифологического интертекста особенно возрастает в прозе XX века. В автобиографическом жанре, с одной стороны, усиливается субъективность, с другой - возрастает степень обобщения и обостряется внимание к мифологическим образам ${ }^{16}$. По словам Н. А. Николиной, в русской автобиографической прозе XX века обнаруживаются две тенденции: „тенденция к своеобразному отчуждению «я» повествователя в прошлом, что приводит к семантической множественности его «я» в тексте, и тенденция к выявлению глубинных мотивов человеческого существования в реконструируемом памятью частном опыте"17. В свою очередь, утраченная целостность „я”, открытие его многослойности и определяют усложнение художественных структур, используемых в автобиографической прозе. Обращение к мифологическим первоосновам - одно из направлений этого процесса. Мифологемы являются источниками образности, схемами моделирующими самопознание и познание человеком мира ${ }^{18}$. Далее исследовательница подчёркивает, что мифологические образы, которые подвергаются в тексте реинтерпретации и трансформации, имеют различный характер. Первый тип - это образы, связанные с античной, древнеиндийской мифологиями и с библейскими текстами. Второй тип восходит к русской сказочно-мифологической традиции. Третий соотносится с историческими деятелями и ситуациями, а также образами, взятыми из литературы и искусства Нового времени ${ }^{19}$.

Мифологические образы, воплощённые в Тени птицы, относятся к первому типу, выделенному Н. А. Николиной. В очерках цикла обнаруживаются античные и древнеиндийские легенды, а также библейские тексты. Однако следует подчеркнуть, что христианских реминисценций намного больше; они доминируют, пронизывая весь текст.

В первом рассказе цикла под таким же заглавием - Тень птицы, рассказчик называет Турцию страной, на которую пала „тень Птицы Хумай”. Он, ссылаясь на строки Саади и на слова его комментаторов, поясняет, что птица Хумай это „легендарная птица и что тень её приносит всему, на что она падает, цар-

\footnotetext{
15 Там же.

16 Н.А. Николина. Поэтика русской автобиографической прозы: учебное пособие. Москва: Флинта: Наука, 2002, с. 379.

17 Там же.

18 Там же.

19 Там же, с. 380.
} 
ственность и бессмертие"20. Приведённая Буниным легенда о птице Хумай раскрывает символику названия всего цикла. Далее рассказчик приводит ещё две легенды, которые рассказывают о происхождении города Константинополя.

Песнью Песней, чудом чудес, столицей земли называли город Константина греческие летописцы. Молва всего мира объясняла его происхождение божественным вмешательством. Одна легенда говорит, что на месте Византии орел Зевса уронил сердце жертвенного быка. Другая - что основателю её было повелено основать город знамением креста, явившимся в облаках над скутарийскими холмами, „при слиянии водных путей и путей караванных”. Но восточный поэт сказал не хуже: „Здесь пала тень Птицы Хумай”.

(И.А. Бунин. Тень птицьь. [В:] Собрание сочинений...., т. 3, с. 515).

Первая из легенд принадлежит античной культуре, вторая относится к христианской мифологии. Повествователь подчёркивает, что город был назван „Песнью Песней” (это, как известно, и заглавие книги Ветхого Завета, авторство которой приписывается „величайшему мудрецу всех времён” - Соломону $^{21}$ ). Выражения с сочетанием единственного и множественного числа (Песнь Песней, чудо чудес) указывают на превосходную степень, важность понятия. Определение „Песнь Песней” по отношению к Константинополю толкуется как богоданный, самыцй лучший, самыцй красивый из всех городов. Поскольку легенды часто повествуют об основании городов, они не могли обойти молчанием главнейшего из них. Приведённые предания очень интересны и образны. Однако, по мнению повествователя, Тезкират Саади сказал о происхождении города „не хуже”. Легенда, о которой упоминает персидский поэт, восходит к иранской и арабской мифологии, а также к арабизированной мифологии народов Средней Азии. Повествователь считает, что легенда о птице, тень которой приносит всему, на что падает, царственность и бессмертие, наиболее поэтична по сравнению с двумя другими. Надо также обратить внимание на наличие в данных легендах существенной мифологемы, а именно символа птицы (Птица Хумай, орел Зевса, „знамение креста, явившиеся в облаках”). Образ птицы появляется в мифологиях и религиях многих народов и чаще всего воспринимается как благоприятный знак. Птица рассматривается как символ Солнца (короля Солнца), ветра, воздуха, времени, божества, Создателя, духа, души 22 Птицы играют важную роль в мифах о создании городов, империй или мира. Они часто воспринимаются как воплощение божества. Символ птицы присутствует ещё в одной легенде, повествующей о возникновении другого известного города. В данном фрагменте описывается не фантастическая, а реальная птица

20 И.А. Бунин. Тень птицы. [В:] Собрание сочинений в шести томах. Произведения 19071914. Т. 3. Москва: Художественная литература, 1987, с. 115. В дальнейшем данное издание цитируется в тексте в скобках с указанием номера страницы.

21 Д.В. Щедровицкий. Соломон. [В:] Мифы народов мира: энциклопедия. Т. 2, с. 460.

22 W. Kopaliński. Ptak. [B:] Słownik symboli. Warszawa: Oficyna Wydawnicza Rytm, 2008, c. 343. 
Настало время, когда над миром восторжествовала грозная и дикая мощь Ислама. Амру, полководец Омара, пришел к Нилу и взял Вавилон. В его палатке свила гнездо голубка. Уходя, Амру оставил палатку, дабы не трогать гнезда. И на этом месте зачался „Победоносный”, Великий Каир.

(И.А. Бунин. Тень птицьь, с. 530).

Древняя легенда рассказывает о событиях, которые якобы имели место в 639 году, когда полководец Амра завоевал Вавилон. В ряде традиций голубь выступает как символ души умершего, небесный вестник ${ }^{23}$. Гнездо, свитое птицей на крыше военной палатки Амра, было признано хорошим предзнаменованием. Предводитель халифа Омара приказал не снимать свою палатку. Она так и осталась на своём месте, когда войска отправились в дальнейший поход.

Следующим символом, с которым связаны многие легенды и которому И. А. Бунин посвятил один из рассказов цикла (Камень), является „Камень Мориа”. Объясняя его, писатель приводит цитату из Талмуда:

Камень Мориа, скала, на которой первый человек принес первую жертву богу, есть средоточие мира. Скалу Мориа, что была покрыта некогда храмом Соломона, а ныне хранима мечетью Омара, положил в основание вселенной сам бог.

(И.А. Бунин. Тень птицьь, с. 554).

Согласно преданиям этот камень находился на одноимённой горе, расположенной на северо-востоке от Иерусалима. На этом месте царь Соломон построил свой первый храм. Туда отправился Авраам, чтобы принести в жертву своего единственного сына ${ }^{24}$.

В дни пророков Камень был внутри святилища храма Соломона, и первосвященник ставил на нем курящуюся кадильницу. На нем же стоял и Ковчег Завета, урна с манной и лежал вечно цветущий жезл Аарона. Ныне Ковчег Завета скрыт в тайниках под Камнем, где сохранял его от врагов сам Соломон, которому Камень давал неземную силу: с него видел царь весь мир от края до края - и понимал язык птиц и зверей.

(И.А. Бунин. Тень птищъl, с. 555).

Во время посещения Буниным этого легендарного места над камнем возвышался уже совсем другой храм - мусульманская мечеть Омара. „Камень Мориа”, „Скала” - это древнейший символ Иудеи. В легендах, приведённых рассказчиком, находится пояснение его истории и значения.

Древние книги и легенды Иудеи и Аравии говорят: „В Иерусалиме бог сказал Скале: ты - основание, от коего начал я создание мира... От тебя воскреснут сыны человеческие из мертвых".

(И.А. Бунин. Тень птищьь, с. 554).

Камень Мориа считается символическим фундаментом мироздания, поскольку, согласно легендам, именно с него Бог начал создание мира. На протя-

23 В.В. Иванов, В.Н. Топоров. Птицыь. [В:] Мифы народов мира: энциклопедия. Т. 2, с. 348.

24 Архимандрит Никифор. Мориа. [В:] Библия. Ветхий и Новый заветы. Синоидальный перевод. Библейская энциклопедия. 1891. [Online:] <http://dic.academic.ru/dic.nsf/biblerus/70737/\% D0\%9C\%D0\%BE\%D1\%80\%D0\%B8\%D0\%B0> (20.07.2017). 
жении веков этот образ-символ принято было называть также „Камнем Основы” или „Камнем Основания” трех религий: иудаизма, христианства и ислама. А вот следующая его характеристика:

Сойдя в пещеру под Скалой, Медшир-ед-Дан видел чудо чудес: колеблющаяся глыба Скалы, ничем и никем не поддерживаемая, висела на высоте, подобно парящему орлу.

(И.А. Бунин. Тень птищьы, с. 554).

„Камень Мориа” по преданию является священным и имеет чудесную силу. В некоторых легендах он даже оживляется и наделяется человеческими чертами:

Магомет - в ночь своего путешествия из Медины в Иерусалим на верблюдице Молнии - „стал своей священной стопою на Скалу Мориа, раскачивающуюся между небом и землею”. Был взмах почти достигший врат рая, - и Скала издала крик радости. Но пророк повелел ей молчать - и вошел во врата рая. А Скала вновь пала к земле - и вновь вознеслась - и в движении своем пребывает и доныне: „не мешаясь с прахом и не смея преступить неба".

(И.А. Бунин. Тень птищьь, с. 554).

Это мусульманское предание связано с историческими событиями. В 638 году Иерусалим был захвачен мусульманами, которые объявили Гору Мориа священным местом ислама и построили на холме два монумента - Аль-Акса и Купол Скалы.

В мифах автор ищет информацию о прошлом, о легендарном плодородии восточных регионов.

Следует ли, говорят некоторые, искать на Ливане отдельных мест, связанных преданием с Эдемом? Не Эдем ли весь Ливан?

(И.А. Бунин. Тень птицьь, с. 577).

Рассказчик приходит к выводу, что напрасно искать конкретные места, упоминаемые в легендах. Жизнь течет, и мир все время изменяется, обогащается. Не стоит постоянно обращаться к прошлому, лучше посмотреть вокруг и увидеть то, что иногда не видно на первый взгляд.

Автор не только обращает внимание на красоту и великолепие посещаемых стран. Он не упускает из виду также их сложное прошлое.

На другой день покидаем Яффу, направляясь по Саронской долине к Иерусалиму.

Пустынный путь! Нарциссы долины, из-за легендарного плодородия которой было пролито столько крови, теперь начинают выпахивать. Иудея опять понемногу заселяется своими прежними хозяевами, страстно мечтающими о возврате дней Давида. Но цветов еще много, слишком много. Всюду мак, мак и мак: щедро усеял он эти пашни и нивы своими огненными лепестками.

(И.А. Бунин. Тень птицы, с. 540).

Рассказчик, с одной стороны, подчёркивает великолепие иудейской земли во времена царя Давида. С другой стороны, он замечает, что эта страна подвергалась бедствиям. Образ выпахиваемых цветов отсылает нас к образу Нарцис- 
са - древнего растительного божества умирающей и воскресающей природы ${ }^{25}$. Красные маки, в свою очередь, символизируют сон и смерть. Происхождение маков часто связывается в мифах с кровью убитого человека. В христианской литературе распространено представление, что маки являются символом невинно пролитой крови ${ }^{26}$. Это может быть намёк на кровь распятого на кресте Христа, или на кровь людей, погибших во время захвата Иудеи Навуходоносором, Персией, Александром Македонским или римлянами.

Одним из самых великих исторических персонажей, упоминаемых в произведении (Море богов), является Александр Македонский.

Александр (...) раздвинул пределы земли, смешал народы и, возвратясь, сказал: „Мир бесконечен, и бог тысячелик. Я поклонялся всем ликам; но истинный - неведом (...)”.

(И.А. Бунин. Тень птицьь, с. 521).

Александр славится как один из величайших полководцев в истории. Он завоевал огромную территорию и подчинил себе многие народы. И хотя он столько увидел в своей жизни, но не нашёл Бога. После его смерти созданная им мировая держава распалась. Имя его, однако, сохранилось в преданиях.

Нередко в цикл вводятся сказания о религиозных деятелях. По мнению Г.А. Левинтона, именно рассказы о жизни и деятельности персонажей священной истории принято называть легендами. В Тени птицы упоминается легенда о бегстве в пустыню Измаила и Агари.

И тайные мольбы и славословия падающего ниц человека со всех концов мира несутся всегда к единому месту: к святому городу, к ветхозаветному камню в пустыне Измаила и Агари...

(И.А. Бунин. Тень птицы, с. 512).

Согласно ветхозаветным и кораническим преданиям, девяностолетняя бездетная Сарра, по обычаю, отдала мужу Аврааму в наложницы свою рабыню Агарь, чтобы та родила ему ребёнка. Родившегося сына назвали Измаилом. Однако спустя некоторое время Сарра сама родила сына Исаака. Между ней и рабыней вспыхнула ссора, и Сарра выгнала Агарь с сыном, а Авраам лишил его права первородства. В связи с данной легендой Измаил считается родоначальником всех арабских племен ${ }^{27}$.

В Шеоле приводится образ ветхозаветного пророка Илии, который за свою жизнь прославился многими чудесами.

Тысячи преданий слили его образ с образом солнечного бога: Илия был питаем вранами, повелевал громами и бурями, низводил огонь и дождь с неба, превращал в камни растения, заживо, как истый сын Солнца, вознесся к нему на пламенной колеснице.

(И.А. Бунин. Тень птицьь, с. 557).

25 К.А. Зурабова, В.В. Сухачевский. Нариисс. [В:] Мифы и предания. Античность и библейский мир: популярный энциклопедический словарь. Москва: Терра, 1993, с. 178.

26 В.Н. Топоров. Мак. [В:] Мифы народов мира: энциклопедия. Т. 2, с. 90.

27 К.А. Зурабова, В.В. Сухачевский. Измаил. [В:] Мифы и предания. Античность и библейский мир: популярный энциклопедический словарь. Москва: Терра, 1993, с. 112. 
Земли, посещаемые рассказчиком, вызывают у него ассоциации с библейскими образами. В Стране содомской упоминается дамасская легенда о Христе, проведшим сорок дней и ночей в пустыне.

Но внизу ещё тень, и, верно, мыши принимают ее за сумерки, когда и создал их Христос. Он сорок дней и ночей провел в пещере над Иерихоном, на обрыве, закрывающем запад, - он не знал, когда садится солнце и когда надлежит совершать молитву. И вот однажды поднялся он на вершину и, как только скрылось солнце, начертал на пыли то легкое, таинственное создание, что так любит сумрак. Он вдохнул в него жизнь и сказал: „Каждый вечер на закате солнца вылетай из расселин горы, где отныне будет твое жилище, дабы знал я час молитвы...”.

(И.А. Бунин. Тень птицьь, с. 569).

В тексте появляется также имя вечного врага Христа - дьявола Азазела, пытавшегося покорить Сына Божьего в пустыне.

Дьявол, Азазел, имя и образ которого так и остались тайной, был издревле владыкой пустыни. Это он обитал в ее знойном серо-каменном море, некогда взбудораженном подземными силами и навсегда застывшем. Это ему каждый год - в десятый день седьмого месяца - посылали левиты и первосвященники Козла Отпущения - от лица всего Израиля, за все грехи его. И не странно ли, что именно оттуда прозвучали первые легенды предтечи!

(И.А. Бунин. Тень птицыь, с. 560).

Легко заметить, что в тексте доминирует христианское миропонимание. Реминисценции из Библии позволяют приблизить и расшифровывать прошлое. Образ Христа в очерках встречается наиболее часто. По мнению рассказчика, с Христом связаны самые красивые легенды на земле.

Как полевой цветок, мало кому ведомый, выросший из случайно занесенного ветром семени в углу покинутого дома, расцвела и здесь легенда, может быть самая прекрасная, самая трогательная: без огня, по бедности родителей, засыпал божественный младенец; мать сидела у его постельки, тихо заговаривая, убаюкивая его; а чтобы не было скучно и жутко ему в наступаюей ночи, светящиеся мушки по очереди прилетали радовать его своим зеленым огоньком. А страна Геннисаретская, где прошла вся молодость его, все годы благовествования, все те дни, незабвенные до скончания века, для них же и был он в мире, - она совсем не сохранила зримых следов его. Но нет страны прелестнее, и нигде так не чувствуется он!

(И.А. Бунин. Тень птицьы, с. 584).

Повествователь подчеркивает, что зримые следы жизни и деятельности Христа не сохранились, но в Вифлееме всё-таки чувствуется его незримое присутствие.

Мифологические образы в цикле путевых поэм Тень птицы наслаиваются и взаимодополняют друг друга. Они отличаются многофункциональностью. Будучи порождением прошлого, они в то же время соотносятся с настоящим и устремлены в будущее. 


\section{Литература}

Аверинцев С.С., Эпштейн М.Н. Мифы. [В:] Литературный энциклопедический словарь. Под ред. В.М. Кожевникова и П.А. Николаева. Москва: Советская энциклопедия, 1987.

Бабореко А.К. Бунин: жизнеописание. Москва: Молодая гвардия, 2009.

Бунин И.А. Тень птищы. [В:] И.А. Бунин. Собрание сочинений в шести томах. Произведения 1907-1914. Т. 3. Москва: Художественная литература, 1987.

Вантенков И.П. Лирические минятюры и путевые поэмы. [В:] Бунин-повествователь (рассказы 1890-1916 г2.). Минск: Издательство Белорусского университета, 1974.

Зурабова К.А., Сухачевский В.В. Нариисс. [В:] Мифы и предания. Античность и библейский мир: популярный энииклопедический словарь. Москва: Терра, 1993.

Зурабова К.А., Сухачевский В.В. Измаил. [В:] Мифы и предания. Античность и библейский мир: популярный энииклопедический словарь. Москва: Терра, 1993.

Иванов В.В., Топоров В.Н. Птищзы. [В:] Мифы народов мира: энииклопедия. Т. 2. Гл. ред. С.А. Токарев. Москва: Советская энциклопедия, 1988.

Исаев Г.Г. Художественная репрезентаиия Ближнего Востока в тирико-документальном дискурсе И. Бунина (иикла путевых поэм «Тень птицыь)). [В:] Художественная картина мира в фольклоре и творчестве русских писателей: Коллективная монография. Под ред. Г.Г. Исаева. Астрахань: Астраханский государственный университет, 2011.

Крутикова Л.В. Комментарии. [В:] Бунин И.А. Собрание сочинений в 9-ти томах. Т. 3. Москва: Художественная литература, 1965-1966.

Левинтон Г.А. Легенды и мифыь. [В:] Мифы народов мира: энциклопедия. Т. 2. Гл. ред. С.А. Токарев. Москва: Советская энциклопедия, 1987.

Мальцев Ю. Иван Бунин 1870-1953. Москва: Посев, 1994.

Никифор, архимандрит. Мориа. [В:] Библия. Ветхий и Новый заветы. Синоидальный перевод. Библейская энииклопедия. 1891. [Online:] <http://dic.academic.ru/dic.nsf/biblerus/70737/\%D 0\%9C\%D0\%BE\%D1\%80\%D0\%B8\%D0\%B0> (20.07.2017).

Николина Н.А. Поэтика русской автобиограбической прозьь: учебное пособие. Москва: Флинта: Наука, 2002.

Таирова И.А. Восточные традиции в творческом восприятии И.А. Бунина. Введение к работе. Москва 2010. [Online:] <http://www.dslib.net/russkaja-literatura/vostochnye-tradicii-vtvorcheskom-vosprijatii-i-a-bunina.html $>$ (30.06.2017).

Токарев С.А., Мелетинский Е.М. Мифология. [В:] Мифы народов мира: энциклопедия. Т. 1. Гл. ред. С.А. Токарев. Москва: Советская энциклопедия, 1987.

Топоров В.Н. История и мифыь. [В:] Мифб народов мира: энииклопедия. Т. 1. Гл. ред. С.А. Токарев. Москва: Советская энциклопедия, 1987.

Топоров В.Н. Мак. [В:] Мифы народов мира: энциклопедия. Т. 2. Гл. ред. С.А. Токарев. Москва: Советская энциклопедия, 1988.

Чистов К.В. Легенда. [В:] Литературный энциклопедический словарь. Под ред. В.М. Кожевникова и П.А. Николаева. Москва: Советская энциклопедия, 1987.

Щедровицкий Д.В. Соломон. [В:] Мифы народов мира: энциклопедия. Т. 2. Гл. ред. С.А. Токарев. Москва: Советская энциклопедия, 1987.

Cieślik K. „Poematy” podróżnicze. [B:] Iwan Bunin (1870-1953). Zarys twórczości. Szczecin: Wydawnictwo Naukowe Uniwersytetu Szczecińskiego, 1998, s. 53-62.

Kopaliński W. Ptak. [B:] Słownik symboli. Warszawa: Oficyna Wydawnicza Rytm, 2008. 